\title{
TROPHIC LINKS OF THE BLACKBIRD (Turdus merula Linnaeus, 1758) IN TRANSFORMED FOREST ECOSYSTEMS OF NORTH-EASTERN UKRAINE
}

\author{
ANZHELA CHAPLYGINA, OLEKSANDR PAKHOMOV
}

Department of Zoology, H. S. Skovoroda Kharkiv National Pedagogical University, 29, Alchevskyh Street, 61002, Kharkiv, Ukraine; e-mail: iturdus@ukr.net

Department of Zoology and Ecology, Oles Honchar Dnipro National University, Gagarin Avenue, 72, 49010, Dnipro, Ukraine; e-mail: a.pakhomov@i.ua

\begin{abstract}
Chaplygina A., Pakhomov O.: Trophic links of the blackbird (Turdus merula Linnaeus, 1758) in transformed forest ecosystems of north-eastern Ukraine. Ekológia (Bratislava), Vol. 39, No. 4, p. 333-342, 2020.

The blackbird (Turdus merula Linnaeus, 1758; Passeriformes, Turdidae) diet was studied to contribute to the conservation of the species population in transformed forests of the north-eastern part of Ukraine. Four forest ecosystems were studied: 3 model sites in the oak forests, transformed under intensive recreation pressure, and 1 model site in a pine-oak forest. A total of 44 invertebrate taxa, dominated by Insecta $(78.1 \%, \mathrm{n}=1075)$, were found. The order Lepidoptera (63.5\%) prevailed. In the diet of blackbird nestlings, the highest number of taxa (37.1-52.2\%) was represented by phytophages. The phytophagous species also constituted the majority of the consumed prey items (58.8-72.0\%). Environmental conditions provided an important effect on the diet structure. The most favourable foraging conditions for the species were found in protected natural areas. According to the analysis, the blackbird foraging efficiency was similar in all the studied sites. The highest biodiversity indices were found in a protected area of Homilshanski Forests National Nature Park. Results of the research have indicated a crucial role of T. merula in the population management of potentially dangerous agricultural pests.
\end{abstract}

Key words: foraging stereotype, diet; dendrophilous birds, zoophages, phytophages, saprophages.

\section{Introduction}

The increasing rate of anthropogenic environmental changes, recorded since the second half of the 20th century, has led to the formation of urban coenoses (Blinkova, Shupova, 2017). To monitor the changes, birds are often used, since their mobility make them convenient indicators of the environment (Gregory et al., 2003; Blair, Johnson, 2008; Bulakhov et al., 2008; Chaplygina et al., 2019). Therefore, studies on the status of insectivorous passerines in the natural communities, exposed to a growing anthropogenic pressure, is one of the main objectives in the contemporary ornithology (Assandri et al., 2017).

The blackbird (Turdus merula Linnaeus, 1758) is a common insectivorous bird and a principal contributor to forest ecosystem communities of the temperate climate zone (Amar 
et al., 2006; Domokos, Domokos, 2016). It is also a migrant of global conservation concern (Bern Convention) (Newton, 2007) and studies on the foraging ecology of the species will definitely assist to its conservation. It has been already revealed that habitat conditions of T. merula are crucial for the successful breeding and stability of its population in forests of Turkey (Karakava, Arican, 2015), Germany (Batary et al., 2014), Sweden (Felton et al., 2016), Romania (Domokos, Domokos, 2016), Spain (Moreno-Rueda, Pizzaro, 2009; Peris, Montelongo, 2014), and countries of Southern Asia (Hamer et al., 2015). The role of artificial light for blackbirds when they search for forage has been also studied (Russ et al., 2015). The letter is especially vital for the north-eastern part of Ukraine, where the natural communities experience strong transformation (Brygadyrenko, 2015; Chaplygina et al., 2016a; Shupova, 2017). In addition, the knowledge of foraging patterns of insectivorous birds is important to prevent outbreaks of the arthropods, being potential carriers of dangerous human diseases (Anderson, Magnarelli, 1993; Lommano et al., 2014), and to mitigate outbreaks of forestry and agricultural pests (Faly, Brygadyrenko, 2014; Chaplygina et al., 2015; Caprio, Rolando, 2017). It also gives an opportunity to control bird flocks which may otherwise destroy part of the harvest (Barnard, 1980; Paralikidis et al., 2009).

Different literary sources discuss a process of the emergence and expansion of synurbanised blackbird populations in European cities (Shukshin, Bokotey, 2016). However, the authors of this paper have found a forest type of the species in the study area. The high number of blackbirds in the forests of North-Eastern Ukraine allows considering it as a subdominant species (Chaplygina, Savinskaya, 2016; Chaplygina, 2018). The timing of this bird migrations (Nadtochiy, Chaplygina, 2010) and the characteristics of their nest locations in Ukraine (Chaplygina, 2009) have been studied as well.

To-date, some researchers suggest that foraging patterns of the species can determine the management and conservation of the bird diversity in natural and transformed areas (Amrhein, 2013; Korňan, Adamík, 2017; Chaplygina, 2018). Changes in breeding habitats are assumed to be potential causes of the reduction of birds in the nesting season (Kirby et al., 2005; Paker et al., 2014). Consequently, they lead to the decline in invertebrates and the loss of feeding habitats for ground-foraging birds (Chaplygina, Savinskaya, 2016; Chaplygina et al., 2016b; Markova, 2016). One of the ways to support the species number and improve the foraging and distribution conditions are suburban river catchments, proposed in South Africa (Suri et al., 2017).

The author have already studied the blackbirds in the forest-steppe zone of Ukraine in comparison with other thrush species (Chaplygina, 2000). However, the diet of this bird in transformed areas requires more thorough inverstigation as it is the main factor that limits the species number.

The aim of this study is to analyse a qualitative and quantitative diet structure and a foraging pattern of the blackbird to reveal trophic links and enhance the conservation of the species populations in the transformed ecosystems of North-Eastern Ukraine.

\section{Material and methods}

The research was carried out over the period 2010-2017, in the forest-steppe zone of Left-bank Ukraine (Kharkiv and Sumy regions). The diet structure of the blackbird nestlings was studied in an upland oak forest of Homilshanski Forests 


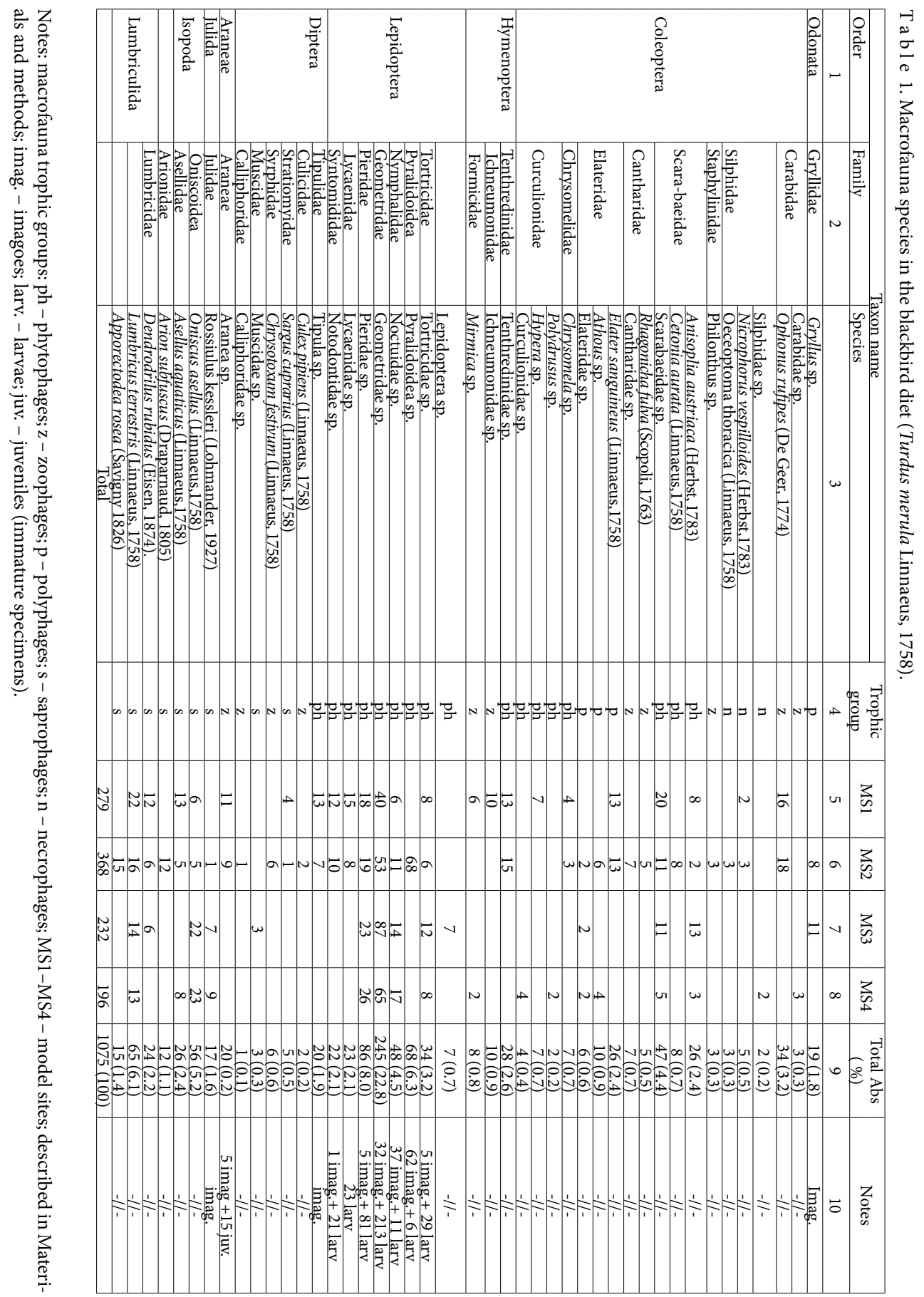



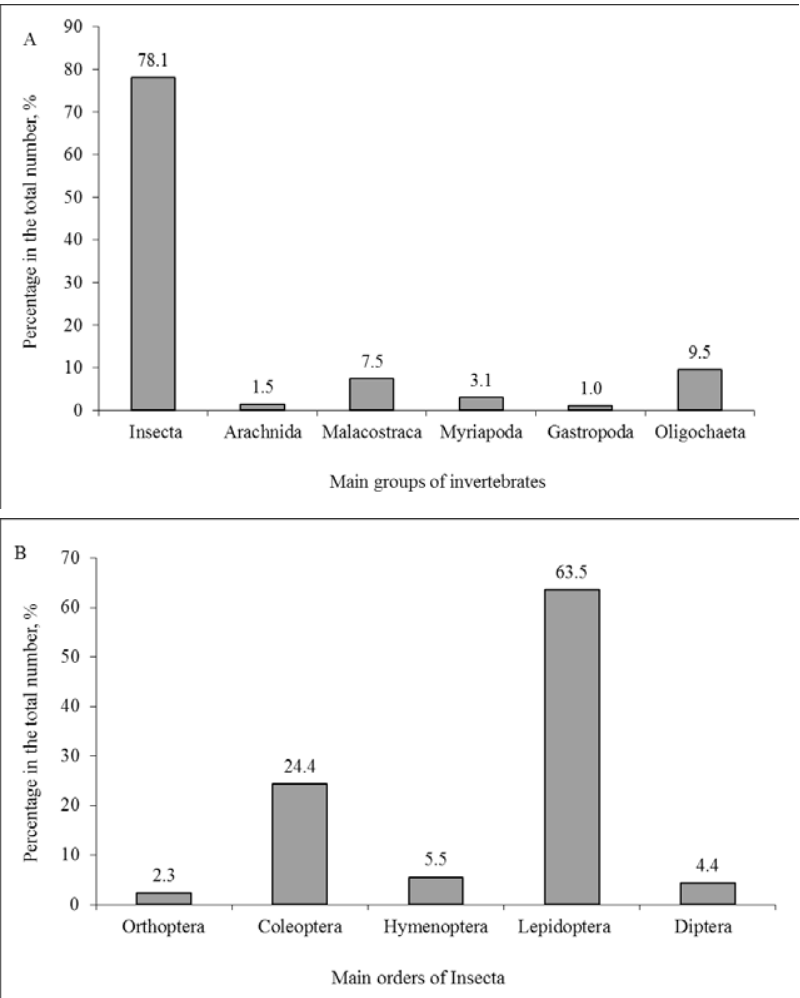

Fig. 1. Diversity of the blackbird trophic links: A - main groups of invertebrates; B - main orders of insects.
National Nature Park (Zmiiv District), in a forest park of Kharkiv, in a pineoak forest of Hetmanskyi National Nature Park (Okhtyrka District), and in Vakalivshchyna Area (Sumy Region) According to Gensiruk's classification (2002), three model sites, selected in the oak forests, were characterized by different stages of recreational digression (transformed as a result of heavy recreation pressure). The fourth model site was located in a pine-oak forest.

Model site 1 (MS1) is situated far from settlements, on the eastern bedrock bank of the Psel River in Vakalivshchyna Area and is represented by an oak forest mixed with some maple and linden trees. The crown closure makes up circa $85 \%$ (Table 1), and the proportion of damaged trees does not exceed $10 \%$ of their total number. The understory and shrub layers, without traits of noticeable damage, are typical for the habitat. The grassy cover is mainly undisturbed and typical for this forest type. In some areas, excessive development of forest herbs is observed, due to the fallout of overmature trees. The forest floor is undisturbed and thick. The recreational coefficient of the site, based on the area of forest paths, comprised 5\%. Model site 1 has the $1^{\text {st }}$ stage of recreational digression.

Model site 2 (MS2) is located within a recreational zone of Hom-

ilshanski Forests National Nature Park, in the vicinities of research sites of H. S. Skovoroda Kharkiv National Pedagogical University and Karazin Kharkiv National University. This area is exposed to intensive recreation pressure during the bird breeding season. The forest includes damaged and diseased trees (about 35\%); the crown closure is about $70 \%$. The understory and shrub layers are available but poorly differentiated. The grassy layer is partly disturbed; projective cover reaches $85 \%$ in some places. The forest floor is slightly disturbed. Forest paths cover up to $30 \%$ of the site. This model site has the $3^{\mathrm{d}}$ stage of recreation digression, and the management of recreation pressure is required.

Model site 3 (MS3) is in the forest park of Kharkiv City. It is a predominantly natural upland oak forest with a small admixture of artificially planted species, located in the interfluve of the Lopan and Kharkiv rivers. The crown closure is circa $60 \%$. The species, typical for the forest edge, as well as meadow, riparian, aquatic, and ruderal plants are recorded. There is an extended network of forest paths and roads, used for jogging. Increased recreation pressure leads to the expansion of open glades and the increasing density of paths. The maple Acer negundo forms dense thickets at the forest edge; in some places, garbage dumps can be found. The number of ruderal species increases as approaching the forest border. The site has the $4^{\text {th }}$ level of recreational digression.

Model site 4 (MS4) is situated in Hetmanskyi National Nature Park, in a pine forest near the villages of Kamianka and Klymetovo, in the area called "Lytovskyi Bir". The oak-pine and maple-linden-oak woodlands near Kamianka have slight signs of human-caused disturbance; diseased trees are found; the crown closure is circa $20 \%$. The understory and shrub layer are typical for the habitat; $5-20 \%$ of the trees have insignificant damages. The grassy layer 
includes meadow grasses $(5-10 \%)$ that is not typical for this type of the forest. The forest floor is slightly disturbed. The area of paths is not extensive and covers up to $10 \%$ of the model site. In the section, lying in Lytovskyi Bir, the area of paths exceeds $20 \%$. In July-August, the recreation pressure increases due to a high number of visitors. However, most bird species finish the breeding season before that time. The site has the $3^{\mathrm{d}}$ level of recreational digression.

A total of 48 blackbird nests with 154 nestlings were inspected and 768 food pellets were collected. Of 1,075 invertebrate specimens, found in the model sites, 279 (taken from 42 nestlings) were in the oak forest MS2, 368 (from 50 nestlings) in the pine-oak forest MS4, 232 (from 34 nestlings) in the oak forest MS1, and 196 (from 28 nestlings) in the oak forest MS3.

The research was carried out from May $25^{\text {th }}$ to June $15^{\text {th }}$ (period 2010-2017) in the first half of the day. The nestling diet was investigated by applying neck ligatures to 5- to 8-dayold chicks (Mal'chevskij, Kadochnikov, 1953). The forage samples were fixed in a $70 \%$ solution of ethanol, and the arthropods were further identified in the laboratory. All the invertebrates were identified to the species, genus or family (in case of significant damage) by Associate Professor PhD Viktor Gramma by standard methods, using reference books.

Statistical treatment of the data was performed in the programme Statistica 8.0 (StatSoft Inc., USA). Similarity coefficients in the species composition of the invertebrates, found in the diet in different sites, were calculated using the formulas of Jaccard $\left(C_{j}=100 \times j /(a+b-j)\right)$ and Sorensen $\left(C_{s}=100 \times 2 j /(a+b)\right)$, where $j-$ the number of invertebrate species found in both groups, $a$ - the number of species in the first group, $b-$ the number of species in the second group. These coefficients ranged from 0 (no similarity between compared parameters) to 1 (complete similarity).

\section{Results}

The blackbird (Turdus merula L.) belongs to the birds, collecting forage in the above-ground layer and, ethologically, is associated with the forest areas rich in herpetobionts. All the birds feed on the ground surface, not pulling invertebrates out of the ground but finding their prey under fallen leaves, stirring the litter, which provides a positive effect on the groundforming processes. Thus, the species prefer habitats with fallen leaves and well-developed ground litter, upper layers of which are difficult to transform. The birds are often found in the

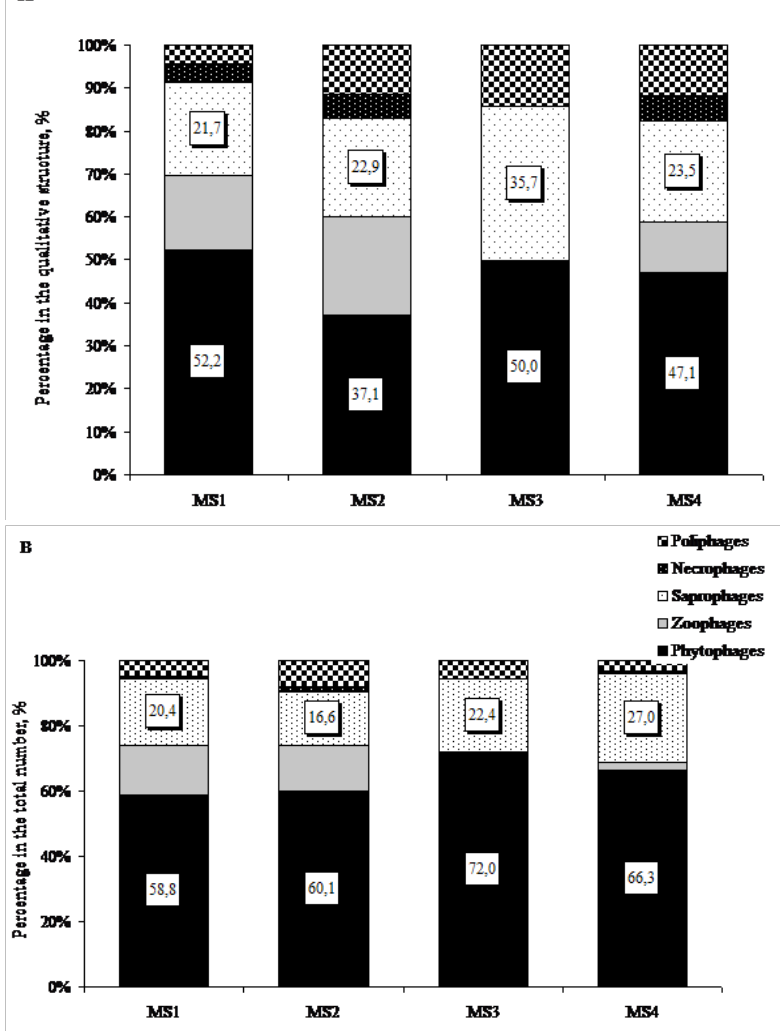

Fig. 2. Distribution of blackbird trophic groups in the model sites: $A$ - percentage in the qualitative structure, $B$ - percentage in the total number. 


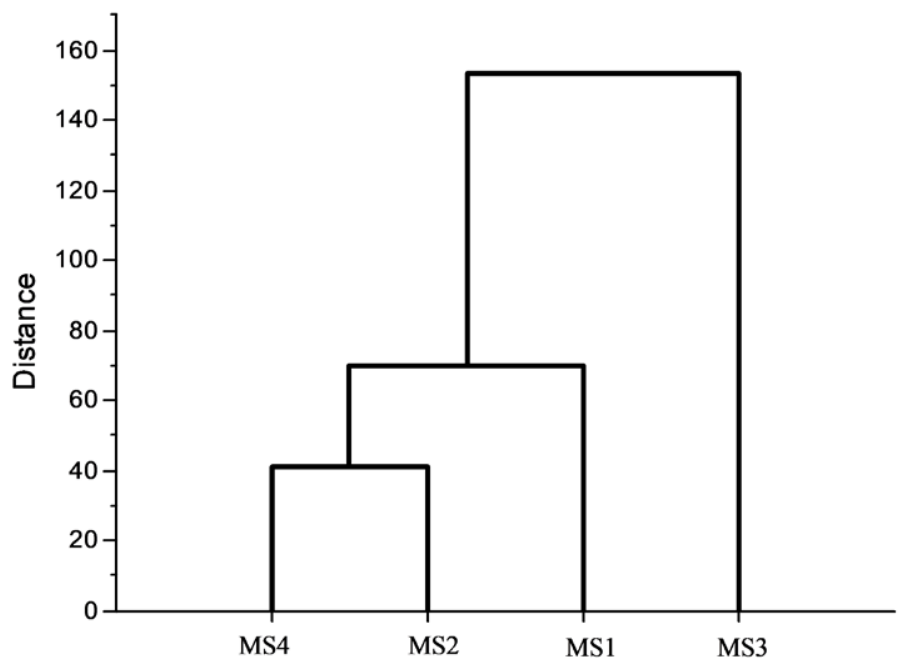

Fig. 3. The similarity of the blackbird trophic links in the studied sites of North-Eastern Ukraine.

$\mathrm{T} \mathrm{a} \mathrm{b}$ l e 2. Indices of diet diversity of the blackbird in model sites of North-Eastern Ukraine.

\begin{tabular}{|l|c|c|c|c|}
\hline \multicolumn{1}{|c|}{ Parameters } & MS1 & MS2 & MS3 & MS4 \\
\hline Number of species & 23 & 35 & 14 & 17 \\
\hline Total number of specimens & 279 & 368 & 232 & 196 \\
\hline Margalef index & 3.91 & 5.75 & 2.39 & 3.03 \\
\hline Menhinnik index & 1.38 & 1.82 & 0.92 & 1.21 \\
\hline Shannon index & 2.96 & 3.05 & 2.17 & 2.25 \\
\hline Simpson dominance index & 0.92 & 0.91 & 0.94 & 0.92 \\
\hline Simpson diversity index & 1.09 & 1.10 & 1.06 & 1.09 \\
\hline Berger-Parker dominance index & 0.14 & 0.18 & 0.38 & 0.33 \\
\hline McIntosh diversity index & 69.25 & 100.60 & 98.37 & 78.66 \\
\hline McIntosh dominance index & 0.80 & 0.77 & 0.62 & 0.64 \\
\hline McIntosh evenness & 0.95 & 0.87 & 0.79 & 0.79 \\
\hline Pielow evenness & 0.66 & 0.60 & 0.57 & 0.55 \\
\hline
\end{tabular}

T a b l e 3. Invertebrate similarity in the blackbird diet in model sites of North-Eastern Ukraine.

\begin{tabular}{|c|c|c|c|}
\hline \multirow{2}{*}{ Pair of model sites } & \multirow{2}{*}{ Number of invertebrate species } & \multicolumn{2}{|c|}{ Similarity index } \\
\cline { 3 - 4 } & & Jaccard & Sorensen \\
\hline MS1 - MS2 & 20 & 52.6 & 69.0 \\
\hline MS3 - MS4 & 10 & 47.6 & 64.5 \\
\hline MS1 - MS4 & 10 & 33.3 & 50.0 \\
\hline MS2 - MS3 & 12 & 32.4 & 49.0 \\
\hline MS1 - MS3 & 9 & 32.1 & 48.6 \\
\hline MS2 - MS4 & 12 & 30.0 & 46.2 \\
\hline
\end{tabular}


areas with a pronounced microrelief of depressions, ground hills and other roughness. These conditions lead to a sharp soil moisture gradient. While feeding, a blackbird moves quickly, usually making $28.5 \pm 2.5(10-40)$ hops and $6.7 \pm 0.8(2-10)$ pecks per minute. The duration of a visual inspection of prey is $1-6$ sec.

Trophic links of the blackbird with 44 taxa of invertebrates were revealed (Table 1). Representatives of Insecta (78.1\%; $n=1075$; of them Lepidoptera caterpillars - 61.5\%; $n=840)$ constituted an absolute majority, while Oligochaeta (9.7\%) and Malacostraca (7.6\%) were found in smaller percentages. Other invertebrate groups (1.0 -3.1\%) were insignificant (Figs 1a, b). The birds pick up Lepidoptera caterpillars from grassy vegetation or from the ground surface, when the latter descend to the ground for pupation or fall on the grass due to the strong wind.

The diet of the blackbird nestlings in all the model sites was dominated by phytophages: from $37.1 \%$ (MS2) and $47.1 \%$ (MS4) to 52.2\% (MS1) and 59.0\% (MS3) in the total number of the species consumed (Fig. 2a). Phytophages also prevailed among prey items: $58.8 \%$ (MS1), $60.1 \%$ (MS2), 66.3\% (MS4) and 72.0\% (MS3) (Fig. 2b). In the breeding season, the blackbirds eradicate phytophages of forest plantations, in particular, larvae of Lepidoptera and Diptera, beetles from the families Curculionidae, Scarabaeidae, etc. Irrespective of the availability of saprophages (Oligochaeta) in their diet, the blackbirds definitely belong to valuable insectivorous birds.

The highest biodiversity indices were revealed in trophic links of the blackbird nestlings in the oak forest with the $3^{\mathrm{d}}$ stage of recreational digression (Fig. 3). However, with the increase of the environment transformation degree in the oak forests with the $1^{\text {st }}$ and $5^{\text {th }}$ stages of recreational digression, the indices show a decreasing trend. McIntosh's and Pielow's evenness indices indicate similar use of prey items in different model sites (Table 2), thus confirming the absence of specificity in the blackbird diet (Aleksandrova, 1959). Shannon diversity index grows from 2.17 (MS3) and 2.25 (MS4) to 2.96 (MS1) and 3.05 (MS2).

Therefore, the blackbirds demonstrate the highest diet similarity in the natural protected areas of the oak forest with the $3^{\mathrm{d}}$ stage of recreational digression (MS2) and in the pine-oak forest with the $3^{d}$ stage of recreational digression (MS4). Trophic links of the blackbird in MS3 were significantly different (Table 3).

\section{Discussion}

In general, the blackbirds play a significant role in the studied ecosystems, regulating the number of invertebrates (Bulakhov et al., 2008). If compare different species for one nesting cycle (averagely, 5 chicks), the song thrushes consume 13,850 $\mathrm{g}$ of biological production, the blackbirds - 18,360 g, and the fieldfares - 21,450 g (the impact of adult birds on the biomass of biocoenoses was not taken into consideration) (Chaplygina, 2000).

The blackbirds have no special diet preferences (Alexandrova, 1959) that makes them quite plastic for the occupation of anthropogenic landscapes (Chaplygina, 2000; 2018). However, we have found a foraging pattern, dominated by representatives of three groups: earthworms, caterpillars and gastropods (Berezantseva, 1997; Baranovsky, 2008). There are also myriapods (Myriapoda), mentioned in the studies of our Belarusian colleagues, as well as click beetles (Elateridae) (Abramova, Haiduk, 2017). During the migration to wintering 
grounds, the birds eat fruits of Cornus sanguinea L., Sambucus nigra L. and Rubus sp. Their preference for the dogwood fruit is probably associated with a high content of lipids that is crucial before the long-distance migration (Hernández, 2009).

\section{Conclusion}

The blackbird diet in human-transformed areas is quite diverse and dominated by Lepidoptera caterpillars, Oligochaeta, and Mollusca. It allows the birds to change the composition of their prey species, depending on the dominance of insects in each particular model site. Further studies on the diet of other insectivorous avian species in these model sites will enhance the identification of functional characteristics of trophic networks in natural and transformed areas, a special role in which is played by polyphagous species with a wide diet range, such as the blackbird.

\section{References}

Abramova, I.V. \& Haiduk V.E. (2017). Ecology of thrush breeding (Turdus, Turdidae, Passeriformes) in South-Western Belarus. In Current issues of zoological science in Belarus: Proceedings of the 11th International Zoological conference dedicated to the 10-year anniversary of the foundation of the Scientific-Practical Bioresources Centre of National Academy of Sciences of Belarus (pp. 8-17). Minsk: A.N. Varaksin Press.

Aleksandrova, I.V. (1959). Materials on the song thrush diet in the breeding season Zoo-logicheskii Zhurnal, 38(1), $137-138$.

Amar, A., Hewson, C., Thewlis, R., Smith, K., Fuller, R., Lindsell, J., Conway, G., Butler, S. \& MacDonald M. (2006). What's happening to our woodland birds? Long-term changes in the populations of woodland birds. RSPB research report number 19, BTO research report number 169. Anon: Sandy and Thetford, RSPB/BTO, 238.

Amrhein, V. (2013). Wild bird feeding (probably) affects avian urban ecology. In D. Gil \& H. Brumm (Eds.), Avian urban ecology (pp. 29-38). Oxford: Oxford University Press. DOI: 10.1093/acprof:osobl/9780199661572.003.0003.

Anderson, J.F. \& Magnarelli L.A. (1993). Epizootiology of Lyme disease-causing borreliae. Clinics in Dermatology, 11(3), 339-351. DOI: 10.1016/0738-081X(93)90088-T.

Assandri, G., Bogliani, G., Pedrini, P. \& Brambilla M. (2017). Insectivorous birds as 'non-traditional' flagship species in vineyards: Applying a neglected conservation paradigm to agricultural systems. Ecological Indicators, 80, 275-285. DOI: 10.1016/j.ecolind.2017.05.012.

Baranovsky, A.V. (2008). The fieldfare (Turdus pilaris), redwing (T. iliacus), song thrush (T. philomelos) and common blackbird (T. merula) In Birds of Ryazan Meshchera (pp. 144-153). Ryazan: Golos Hubernii.

Barnard, C.J. (1980). Flock feeding and time budgets in the house sparrow (Passer domesticus L.). Anim. Behav., 28(1), 295-309. DOI: 10.1016/s0003-3472(80)80032-7.

Batary, P., Fronczek, S., Normann, C., Scherber, C. \& Tscharntke T. (2014). How do edge effect and tree species diversity change bird diversity and avian nest survival in Germany's largest deciduous forest? For. Ecol. Manag., 319(7), 44-50. DOI: 10.1016/j.foreco.2014.02.004.

Berezantseva, M.S. (1997). The diet of the common blackbird nestlings Turdus merula and its comparison with the diet of the song thrush nestlings T. philomelos in the forest-steppe oak woodland "Forest on the Vorskla". Russian Ornithological Journal, 20(6), 12-20.

Blair, R.B. \& Johnson E.M. (2008). Suburban habitats and their role for birds in the urban-rural habitat network: Points of local invasion and extinction. Landsc. Ecol., 23(10), 1157-1169. DOI: 10.1007/s10980-008-9267-y.

Blinkova, O. \& Shupova T. (2017). Bird communities and vegetation composition in the urban forest ecosystem: correlations and comparisons of diversity indices. Ekológia (Bratislava), 36(4), 366-387. DOI: 10.1515/eko-2017-0029.

Brygadyrenko, V.V. (2015). Community structure of litter invertebrates of forest belt ecosystems in the Ukrainian steppe zone. International Journal of Environmental Research, 9(4), 1183-1192. DOI: 10.22059/IJER.2015.1008.

Bulakhov, V.L., Gubkin, A.A., Ponomarenko, O.L. \& Pakhomov O.Y. (2008). Biological diversity of Ukraine. Dnipropetrovsk region. Aves: Non-passeriformes (in Ukrainian). Dnipropetrovsk: Dnipropetrovsk University Press. 
Bulakhov, V.L., Gubkin, A.A., Ponomarenko, O.L. \& Pakhomov O.Y. (2015). Biological diversity of Ukraine. Dnipropetrovsk region. Aves: Passeriformes (in Ukrainian). Dnipropetrovsk: Dnipropetrovsk University Press.

Caprio, E. \& Rolando A. (2017). Management systems may affect the feeding ecology of great tits Parus major nesting in vineyards. Agric., Ecosyst. Environ., 243, 67-73. DOI: 10.1016/j.agee.2017.03.013.

Chaplygina, A.B. (2000). On the issue of a biocoenotical role of birds in ecosystems (by the example of the genus Turdus). In Birds of the Seversky Donets basin. Proceedings of the 6th and 7th Conferences on "Study and Protection of Birds of the Seversky Donets River Basin" (pp. 51-57). Donetsk.

Chaplygina, A.B. (2009). Patterns of nest location of thrushes of the genus Turdus in transformed landscapes of North-East Ukraine (in Ukrainian). Berkut, 18(1-2), 135-142.

Chaplygina, A.B., Gramma, V.N., Bondarets, D.I. \& Savynska N.O. (2015). Arthropods in a trophic-coenosis structure of the collared flycatcher consortium in conditions of forest ecosystems of North-Eastern Ukraine. Visnyk of Dnipropetrovsk University. Biology, Ecology, 23(1), 74-85. DOI: 10.15421/011511.

Chaplygina, A.B. \& Savinskaya, N.O. (2016). Current status of the avifauna of transformed landscapes of NorthEastern Ukraine by the example of Muscicapidae and Turdidae. Russian Ornithological Journal, 25(1252), 615-647.

Chaplygina, A.B., Yuzyk, D. \& Savyns'ka N.O. (2016a). The robin, Erithacus rubecula (Passeriformes, Turdidae) as a component of autotrophic consortia of forest coenoses, Northeast Ukraine. Vestn. Zool., 50(4), 369-378. DOI: 10.1515/vzoo-2016-0043.

Chaplygina, A.B., Yuzyk, D.I. \& Savyns'ka N.O. (2016b). The robin, Erithacus rubecula (Passeriformes, Turdidae), as a component of heterotrophic consortia of forest cenoses, Northeast Ukraine. Part 2. Vestn. Zool., 50(6), 493-502. DOI: 10.1515/vzoo-2016-0056.

Chaplygina, A.B. (2018). Dendrophilic passerines (Passeriformes) as a structural-functional element of anthropogenically transformed forest biogeocoenoses of North-Eastern Ukraine. Dnipro: Oles Honchar Dnipro National University.

Chaplygina, A.B., Pakhomov, O.Y. \& Brygadyrenko V.V. (2019). Trophic links of the song thrush (Turdus philomelos) in transformed forest ecosystems of North-Eastern Ukraine. Biosystems Diversity, 27(1), 51-55. DOI: $10.15421 / 011908$

Domokos, E. \& Domokos J. (2016). Bird communities of different woody vegetation types from the Niraj Valley, Romania. Turk. J. Zool., 40, 734-742. DOI:10.3906/zoo-1510-64.

Faly, L.I. \& Brygadyrenko V.V. (2014). Patterns in the horizontal structure of litter invertebrate communities in windbreak plantations in the steppe zone of the Ukraine. Journal of Plant Protection Research, 54(4), 414-420. DOI: 10.2478/jppr-2014-0062.

Felton, A., Hedwall, P.O., Lindbladh, M., Nyberg, T., Felton, A.M., Holmström, E., Wallin, I., Lof, M. \& Brunet J. (2016). The biodiversity contribution of wood plantations: Contrasting the bird communities of Sweden's protected and production oak forests. For. Ecol. Manag., 365(1), 51-60. DOI: 10.1016/j.foreco.2016.01.030.

Gensiruk, S.A. (2002). Forests of Ukraine (in Ukrainian). Lviv: Schevchenko Scientific Society.

Gregory, R.D., Noble, D.G., Field, R.O, Marchant, J.H., Raven, M.J. \& Gibbons D.W. (2003). Using birds as indicators of biodiversity. Ornis Hungarica, 12-13, 11-24.

Hamer, K.C., Newton, R.J., Edwards, A.F., Benedick, S.I., Bottrell, S.H. \& Edwards D.P. (2015). Impacts of selective logging on insectivorous birds in Borneo: The importance of trophic position, body size and foraging height. Biol. Conserv., 188, 82-88. DOI: 10.1016/j.biocon.2014.09.026.

Hernández, A. (2009). Summer-autumn feeding ecology of Pied Flycatchers Ficedula hypolueca and Spotted Flycatchers Muscicapa striata: The importance of frugivory in a stopover area in north-west Iberia. Bird Conserv. Int., 19, 224. DOI: 10.1017/s0959270909008351

Karakava, M. \& Arican K. (2015). The nest-site characteristics of the forest population of Common Blackbird (Turdus merula) in Eskişehir, Turkey. Turk. J. Zool., 39(2), 295-299. DOI: 10.3906/zoo-1401-36.

Kirby, W., Black, K., Pratt, S. \& Bradbury R. (2005). Territory and nest-site habitat associations of Spotted Flycatchers Muscicapa striata breeding in central England. Ibis, 147, 420-424. DOI: 10.1111/j.1474-919x.2005.00425.

Korňan, M. \& Adamík P. (2017). Tree species preferences of foraging insectivorous birds in a primeval mountain mixed forest: Implications for management. Scand. J. For. Res., 32, 1-8. DOI: 10.1080/02827581.2017.1299211.

Lommano, E., Dvořák, C., Vallotton, L., Jenni, L. \& Gern L. (2014). Tick-borne pathogens in ticks collected from breeding and migratory birds in Switzerland. Ticks and Tick-borne Diseases, 5(6), 871-882. DOI: 10.1016/j. ttbdis.2014.07.001. 
Malchevskij, A.S. \& Kadochnikov A.S. (1953). A method of in vivo study of the nestling diet of insectivorous birds. Zoologicheskij Zhurnal, 32(2), 227-282.

Markova, A.O. (2016). Aggressive behaviour of Robins Erithacus rubecula (Passeriformes, Muscicapidae) at watering places in the forest-steppe zone of Ukraine. Visnyk of Dnipropetrovsk University. Biology, Ecology, 24(2), 283-289. DOI: $10.15421 / 011636$.

Moreno-Rueda, G. \& Pizzaro M. (2009). Relative influence of habitat heterogeneity, climate, human disturbance, and spatial structure on vertebrate species richness in Spain. Ecol. Res., 24(2), 335-344. DOI: 10.1007/s11284008-0509-x.

Nadtochiy, A.S. \& Chaplygina A.B. (2010). Long-term changes in timing of bird arrival in Kharkov region (in Russian). Branta, 13, 50-61.

Newton, I. (2007). The Palaearctic-Afrotropical migration system. In I. Newton (Ed.), The migration ecology of birds (pp. 699-727). Academic Press. DOI: 10.1016/B978-012517367-4.50024-3.

Paker, Y., Yom-Tov, Y., Alon-Mozes, T. \& Barnea A. (2014). The effect of plant richness and urban garden structure on bird species richness, diversity and community structure. Landsc. Urban Plann., 122, 186-195. DOI: 10.1016/j.landurbplan.2013.10.005.

Paralikidis, N., Papageorgiou, N., Tsiompanoudis, A. \& Kontsiotis V. (2009). Song thrush Turdus philomelos winter diet in Mediterranean habitats: A case study in Greece. Avocetta Journal of Ornithology, 33, 109-111.

Peris, S. \& Montelongo T. (2014). Birds and small urban parks: a study in a high plateau city. Turk. J. Zool., 38, 316-325. DOI: 10.3906/zoo-1305-20.

Russ, A., Rüger, A. \& Klenke R. (2015). Seize the night: European Blackbirds (Turdus merula) extend their foraging activity under artificial illumination. Journal of Ornithology, 156(1), 23-31. DOI: 10.1007/s10336-014-1105-1.

Shukshin, O.O. \& Bokotey A.A. (2016). Synurbization and changes in quantity of the blackbird in Europe and Ukraine. Proceedings of the State Natural History Museum, 32, 91-102.

Shupova, T.V. (2017). Transformation in the diversity of avifauna under the influence of recreational load (in Russian). Biosystems Diversity, 25(1), 45-51. DOI: 10.15421/011707.

Suri, J., Anderson, P., Charles-Dominique, T., Hellard, E. \& Cumming G. (2017). More than just a corridor: A suburban river catchment enhances bird functional diversity. Landsc. Urban Plann., 157, 331-342. DOI: 10.1016/j. landurbplan.2016.07.013. 